\title{
AN ANALYSIS OF RADIATION WORKER SAFETY AT SAMOP FACILITY PSTA-BATAN YOGYAKARTA USING MCNP6
}

\author{
R Riyadi ${ }^{1}$, Suharyana ${ }^{1 *}$, F Anwar $^{1}$, Riyatun $^{1}$, Soeparmi $^{1}$ \\ 1) Physics Departement, Faculty of Mathematics and Science, Sebelas Maret University \\ *Corresponding author: suharyana61@staff.uns.ac.id
}

\begin{abstract}
ABSTRAK
ANALISIS KEAMANAN PEKERJA RADIASI DI FASILITAS SAMOP PSTA-BATAN YOGYAKARTA MENGGUNAKAN MCNP6. Telah dilakukan perhitungan simulasi dosis $\gamma$ yang diterima pekerja radiasi di sekitar SAMOP menggunakan MCNP6. Bahan bakar SAMOP dimodelkan pada larutan uranil nitrat $\left(\mathrm{UO}_{2}\left(\mathrm{NO}_{3}\right)_{2}\right)$ dengan pengayaan $19,75 \%$ dan konsentrasi $300 \mathrm{~g}$ U/L. SAMOP dioperasikan dengan daya 600 watt dan terbakar selama 6 hari menggunakan ORIGEN2. Dari simulasi, membakar informasi yang diperoleh kontribusi radiasi $\gamma$ digunakan untuk menghitung dosis yang diterima oleh pekerja radiasi. Perhitungan laju dosis menggunakan MCNP6 pada jarak $225 \mathrm{~cm}$ dari SAMOP tanpa perisai memperoleh hasil dosis $\gamma$ jumlah $(11.217,39 \pm 0,35) \mu \mathrm{Sv} / \mathrm{jam}$ dengan perkiraan waktu kerja pekerja radiasi pada 0,02 jam / minggu. Penambahan pelindung beton barit dengan ketebalan $47,69 \mathrm{~cm}$ pada jarak $225 \mathrm{~cm}$ dari SAMOP dengan menggunakan pendekatan ekstrapolasi berdasarkan variasi ketebalan pelindung dari hasil perhitungan simulasi diperoleh laju dosis $\gamma 5,21 \mu \mathrm{Sv} / \mathrm{jam}$ dan estimasi waktu maksimum kerja $36,98 \mathrm{jam} / \mathrm{minggu}$.
\end{abstract}

Kata kunci: analisis, keselamatan, mcnp6, pekerja

\section{ABSTRACT}

AN ANALYSIS OF RADIATION WORKER SAFETY AT SAMOP FACILITY PSTA-BATAN YOGYAKARTA USING MCNP6. It has been done the calculation of $\gamma$ dose simulation received radiation worker around SAMOP using MCNP6. The fuel SAMOP was modeled on the solution of uranyl nitrate $\left(\mathrm{UO}_{2}\left(\mathrm{NO}_{3}\right)_{2}\right)$ with enrichment of $19.75 \%$ and a concentration of $300 \mathrm{~g}$ U/L. SAMOP was operated on a power of 600 watts and burn up for 6 days using ORIGEN2. From the simulation, burn up acquired information $\gamma$ radiation contribution used to calculate the dose received by radiation workers. The Calculation of the dose rate using MCNP6 at a distance of $225 \mathrm{~cm}$ from SAMOP without shielding obtained the result of $\gamma$ dose the amount of $(11,217.39 \pm 0.35) \mu S v / h o u r$ with the estimated working time of radiation workers at 0.02 hours/week. The addition of the barite concrete shielding with a thickness of $47.69 \mathrm{~cm}$ at a distance of $225 \mathrm{~cm}$ from SAMOP using an extrapolation approach based on the variation of the shielding thickness of simulation calculation results obtained $\gamma$ dose rate of $5.21 \mu \mathrm{Sv} / \mathrm{hour}$ and estimated time maximum work of 36.98 hours/week.

Key words: analysis, mcnp6, safety, worker

\section{INTRODUCTION}

Radioisotope ${ }^{99}$ Mo used for diagnostic in nuclear medicine. ${ }^{99} \mathrm{Mo}$ is the parent radionuclide which decays to produce ${ }^{99 \mathrm{~m}} \mathrm{Tc}$. Radioisotope ${ }^{99 \mathrm{~m}} \mathrm{Tc}$ has the characteristic of emitting $\gamma$ energy of $140.5 \mathrm{keV}$ and a half-life of 6 hours. Both of these properties are very suitable for diagnostic purposes in bone, brain, thyroid, lung, liver, kidney and body metabolism systems $[1,2]$.

In Indonesia, the National Nuclear Energy Agency (BATAN) through the Science and Technology Accelerator Center (PSTA) has developed Subcritical Assembly for ${ }^{99} \mathrm{Mo}$ Production (SAMOP) as a solution to increase 
the supply of ${ }^{99} \mathrm{Mo}$ especially in Indonesia [1]. SAMOP uses the Low Enriched Uranium (LEU) fuel, which is uranyl nitrate solution $\left(\mathrm{UO}_{2}\left(\mathrm{NO}_{3}\right)_{2}\right)$ and operated in subcritical conditions with a neutron multiplication factor $\left(k_{\text {eff }}\right)$ of less than 1 or $0,97 \leq k_{\text {eff }} \leq 0,99$ [3]. The thermal neutron source is taken from one of the Kartini neutron beam port reactors.

In addition to reactor safety, nuclear technology must pay attention to the safety and security of workers around the reactor. The purpose of work safety is to prevent nonstochastic (deterministic) effects and avoid the possibility of stochastic effects on radiation receiver [4]. Based on recommendations from ICRP No. 60 of 1990 to meet the objectives of radiation safety and protection for workers in nuclear installations, it explains several principles of radiation protection that must be carried out, namely justification, optimization, and limitation. Dose Limit Value (NBD) determined based on Government Regulation No. 33 of 2007 concerning occupational safety against ionizing radiation and the safety of radioactive sources permitted by the National Nuclear Energy Supervisory Agency (BAPETEN) the dose that can be received by radiation workers without causing effects to the body is $20 \mathrm{mSv}$ on average per year or a dose that accumulates in five years no more than $100 \mathrm{mSv}$. Information about radiation doses around SAMOP is needed. If the measured dose exceeds the NBD, then dose limitation is required, which includes setting the distance, time and use of the radiation shield.

To review the safety aspects, it is necessary to burn up for six days [5] and analyze the yield of a nuclide. The absorbed dose is measured at several points around SAMOP by using the information on the nuclide activity of the burn-up as a source of radiation. If the dose accumulated in one year at that point exceeds the NBD value, a SAMOP geometric design model is created by adding a radiation shield on the side of the reactor with barite concrete variations in thickness. Dose calculation is done using the Monte Carlo method, which is a method for tracking particle trips and calculating all interactions that may occur in particles from particles born to disappearing. Some Monte Carlo based software includes MCNP, SCALE and MVP. In this study, MCNP6 software is used because of its flexible ability to present geometry and can calculate the dose caused by various radiation particles around SAMOP. ORIGEN2 is used for the burn-up process because ORIGEN 2's computing time is shorter than MCNP6.

According to research that has been done by Rasito, et al. (2016) [6] shows that the ability of barite type concrete to reduce radiation $\gamma$ is greater than port and concrete. In the research of Akkurt, et al. (2010) [7] showed that barite concrete could be used as a good alternative to radiation shield $\gamma$. In this research, barite concrete is used as an alternative to radiation shield $\gamma$. The reason for choosing this material is because it is effective for reducing $\gamma$ radiation and easily made models of radiation shielding.

\section{METHODOLOGY}

The fuel material is uranyl nitrate solution with $19.75 \%$ enrichment. The concentration of the solution is $300 \mathrm{~g} / \mathrm{L}$ and the volume is $24.382 \mathrm{~L}$. Uranium density of 2,087 $\mathrm{g} / \mathrm{cc}, \mathrm{UO}_{2}\left(\mathrm{NO}_{3}\right)_{2} \cdot 6 \mathrm{H}_{2} \mathrm{O}$ of $2,807 \mathrm{~g} / \mathrm{cc}$ and $\mathrm{H}_{2} \mathrm{O}$ of $0,997047 \mathrm{~g} / \mathrm{cc}$ [5]. The output of ORIGEN2 is in the form of a mass of nuclides, which has a mass of more than $10^{-9}$ grams and a half-life of more than 22 hours. From the mass (m) we can calculate the activity ( $R$ ) of the nuclide using equation (1).

$$
R=\frac{m}{M A} \times N_{A} \times \frac{\ln 2}{T_{1 / 2}}
$$

With MA is the relative atomic mass, NA is the Avogadro constant $\mathrm{N}_{\mathrm{A}}=6,02 \times 10^{23}$ and $T_{1 / 2}$ is the half-life of the nuclide.

$\gamma$ dose calculation was performed at 6 soft tissue positions around SAMOP using MCNP6. Soft tissue has the same elements as the human body and complies with ICRP recommendations used as a detector. The radiation source used is the nuclide activity of the burn-up results in the form of a point at the center of SAMOP spreading in all directions (isotrope). Tally F4 is used to calculate doses that pass through soft tissue with conversion of dose energy (DE), fluent dose (DF), and normalization (fm). Addition of barite concrete shielding $(\rho=3.35 \mathrm{gr} / \mathrm{cc})$ was done with thickness variations to get a dose less than NBD. For the calculation of the estimated radiation worker time using equation (2)

$$
D=D^{\circ} t
$$


With $D$ is the dose received by the radiation worker, $D$ is the dose rate in the radiation field and $t$ is the irradiation time. In this study, the radiation worker time is assumed to be 1980 hours/year. The radiation shield design is shown in Figure 1.

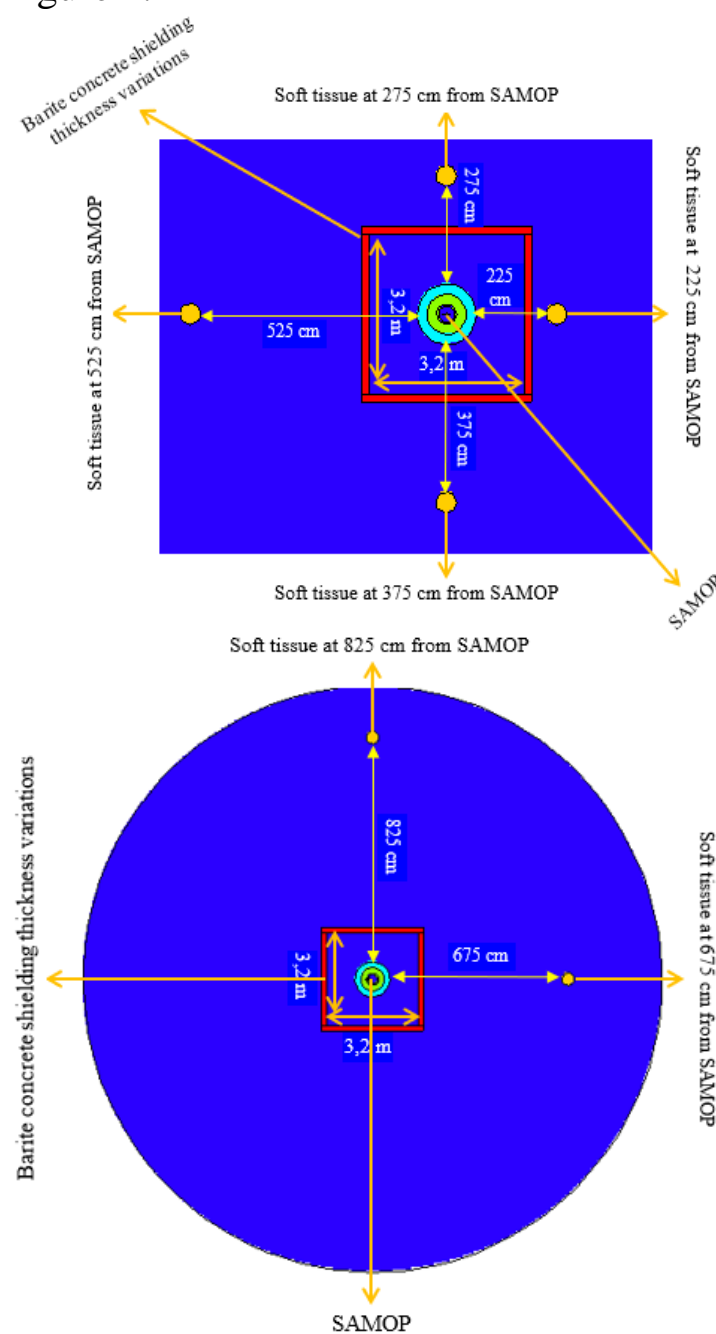

Figure 1 . The projected VISED geometry radiation shield design appears in the XY plane

\section{RESULT AND DISCUSSION}

A summary of ORIGEN2 output in the form of mass (grams) is shown in Table 1 for gas phase fission products and Table 2 for other phase nuclides. Nuclides resulting from fission of the gas phase with high activity are the elements Xenon and Krypton, which belong to noble gas atoms, cannot be bound in chemical compounds. This phase can enter the respiratory system of humans and animals, or stick to trees or leaves that also have the potential to enter the digestive system of humans and animals through the food process. High activity from ${ }^{135} \mathrm{Xe},{ }^{133} \mathrm{Xe}$ and ${ }^{85} \mathrm{Kr}$ which has a long half-life must be handled properly, so it does not become a dangerous environmental polluter. Therefore it is necessary to make a gas sealing shield so it does not come out into the environment.

Table 1. Fission products of gas phase separating results

\begin{tabular}{|c|c|c|c|c|}
\hline Nuclide & $\begin{array}{c}\text { Mass } \\
(\mu \mathrm{g})\end{array}$ & $\begin{array}{l}\text { Activity } \\
\text { (Ci) }\end{array}$ & Half-life & $\begin{array}{l}\gamma \text { energy } \\
(\mathrm{keV})[7]\end{array}$ \\
\hline${ }^{185} \mathrm{Xe}$ & 12.95 & 33.80 & 9.14 hour & 249.794 \\
\hline${ }^{2 x} \mathrm{Xe}$ & 82.03 & 15.538 & 5.24 day & 80.990 \\
\hline${ }^{2 x s m} \mathrm{Xe}$ & 1.667 & 0.754 & 2.19 day & 233.310 \\
\hline${ }^{z_{\mathrm{Kr}}}$ & 3.519 & 0.0014 & 10.73 years & 513.997 \\
\hline${ }^{n} \mathrm{~s}_{\mathrm{Kr}}$ & 0.777 & 6.49 & 4.48 hours & 151.195 \\
\hline
\end{tabular}

Table 2. Fission results with non-gas phases

\begin{tabular}{|c|c|c|c|c|}
\hline Nuclide & $\begin{array}{l}\text { Mass } \\
(\mu \mathrm{g})\end{array}$ & $\begin{array}{c}\text { Activity } \\
\text { (Ci) }\end{array}$ & Decay & $\begin{array}{l}\gamma \text { energy } \\
(\mathrm{keV}) \text { [7] }\end{array}$ \\
\hline${ }^{218 \pi} \mathrm{I}$ & 29.64 & 35.120 & $\beta^{-}, \gamma, X$ & 529.87 \\
\hline${ }^{142} \mathrm{Ce}$ & 42.72 & 28.900 & $\beta^{-}, \gamma, \mathrm{X}$ & 293.27 \\
\hline${ }^{*} \mathrm{Mo}$ & 49.36 & 24.440 & $\beta^{-}, \gamma, \mathrm{X}$ & 739.50 \\
\hline${ }^{142} \mathrm{Ba}$ & 119.40 & 8.897 & $\beta^{-}, \gamma, X$ & 537.26 \\
\hline${ }^{2 x} \mathrm{~Np}$ & 33.38 & 7.801 & $\beta^{-}, \gamma, X$ & 106.12 \\
\hline${ }^{149} \mathrm{La}$ & 10.27 & 5.748 & $\beta^{-}, \gamma$ & 1596.21 \\
\hline${ }^{281} \mathrm{I}$ & 44.43 & 5.693 & $\beta^{-}, \gamma, X$ & 364.49 \\
\hline
\end{tabular}

In terms of its radio-toxicity, some of the nuclides from fission in Table 1 and Table 2 have various categories of radio-toxicity. Based on the Council of the European Communities and the provisions of BATAN [8] it can be obtained information of nuclides that have high radio-toxicity such as ${ }^{131} \mathrm{I}$, ${ }^{144} \mathrm{Ce},{ }^{89} \mathrm{Sr}$, ${ }^{126} \mathrm{Sb}$, and ${ }^{156} \mathrm{Eu}$. Meanwhile, nuclides that have moderate radio-toxicity include ${ }^{137} \mathrm{Cs},{ }^{91} \mathrm{Y},{ }^{95} \mathrm{Zr},{ }^{140} \mathrm{Ba},{ }^{125} \mathrm{Sn}$, and ${ }^{143} \mathrm{Pr}$. For nuclides which have low radiotoxicity i.e., ${ }^{85} \mathrm{Kr},{ }^{136} \mathrm{Cs}$, and ${ }^{238} \mathrm{U}$ nat. Based on the radio-toxicity, the extraction process of fission must be very thorough so that it can be separated ${ }^{99}$ Mo with high purity, not mixed with toxic nuclides.

Some important nuclides besides ${ }^{99} \mathrm{Mo}$ which are also beneficial to the medical world resulting from SAMOP burn-up include ${ }^{131} \mathrm{I}$ with activity $5.690 \mathrm{Ci}$ and ${ }^{133} \mathrm{Xe}$ with activity 15.540 $\mathrm{Ci}$. The two nuclides are each used for examination of the thyroid gland [9] and for detecting lung disease [10]. 
The SAMOP room design is assumed to be square in size $320 \mathrm{~cm}$ x 320 with a height of $500 \mathrm{~cm}$. The shape of the room is designed like a confinement so that the nuclides resulting from fission by the gas phase do not come out into the environment. The VISED geometry of the room design is shown in Figure 2.

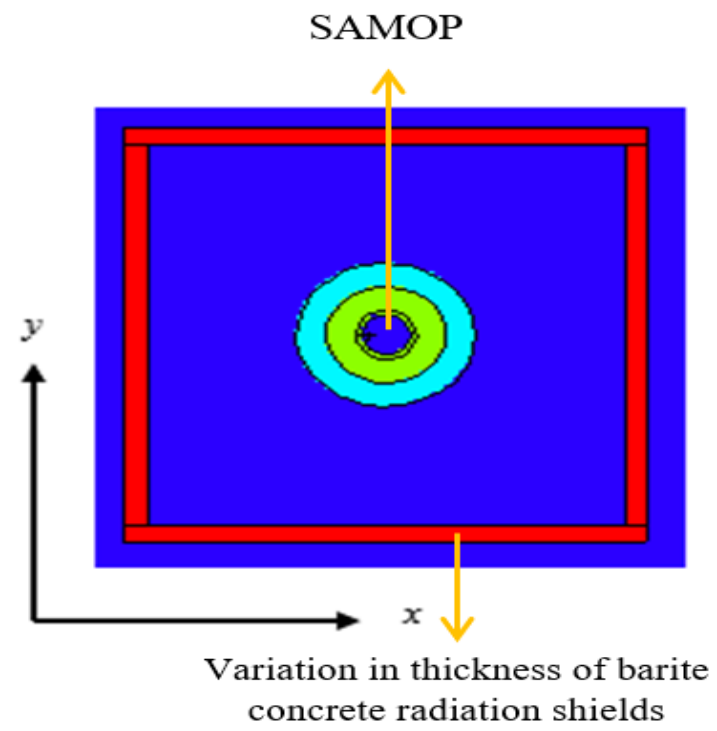

(a)

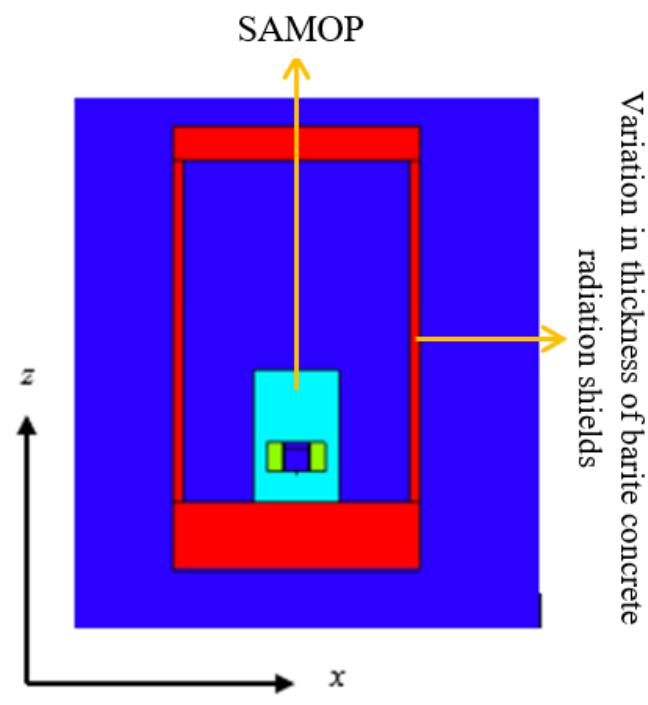

(b)

Figure 2. Projection geometry design VISED radiation shield SAMOP visible (a) top (b) side

Radiation shielding material used in this study is barite concrete with a density of 3.35 gr. $\mathrm{cm}^{-3}$ referring to research conducted by Rasito, et al (2016) [6] showing that the ability of barite type concrete to reduce $\gamma$ radiation is greater than that of Portland concrete. This is because barite concrete contains more iron atoms with an atomic fraction of 0.026213 and there are $10 \%$ barium atoms. In the research of Akkurt, et al (2010) [7] showed clearly that barite concrete could be used as a good alternative for $\gamma$ radiation shielding other than lead. In another study, Ouda, et al (2015) [11] regarding $\gamma$ radiation shielding from a variety of heavy concrete also showed that barite concrete is quite effective even under magnetite.

Figure 3 displays a graph of the simulation results of the calculation of the dose rate with variations in the thickness of the radiation shield at a certain distance. Figure 3 shows that the dose rate on soft tissue will decrease exponentially with the thickness of the radiation shield at a certain distance.

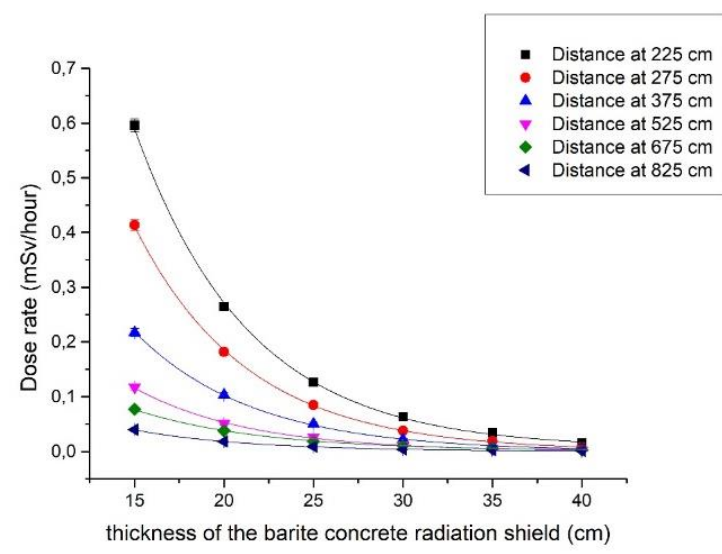

Figure 3. Graph of the relation between the thickness of barite concrete radiation shields to the dose rate at a certain distance

In a radiation facility a constraint dose is applied as a barrier and a lower dose is determined than the NBD. This value is used in terms of the facility optimization process with the aim of ensuring that the NBD is not exceeded. In this study, it is assumed that the constraint dose of $10 \mathrm{mSv}$ per year is based on ICRP 60 [12]. To find out the thickness of the radiation shield is done by extrapolation approach based on 6 simulation data. From Figure 3 we get a modified line equation by changing the variable, i.e. the independent variable is the dose rate $(\mu \mathrm{Sv} / \mathrm{hr})$ received by soft tissue at a certain distance, and the dependent variable is the thickness of the radiation shield $(\mathrm{cm})$. The results of calculating the optimum radiation shield thickness, according to the constraint dose are shown in Table 3. 
Table 3. Radiation shield thickness estimation according to constraint dose

\begin{tabular}{cccc}
\hline $\begin{array}{c}\text { Distance } \\
(\mathbf{c m})\end{array}$ & Line equation & $\mathbf{R}^{2}$ & $\begin{array}{c}\text { Thickness } \\
(\mathbf{c m})\end{array}$ \\
\hline 225 & $y=-6,987 \ln (\mathrm{x})+59,221$ & 0,998 & 47,69 \\
275 & $y=-6,338 \ln (\mathrm{x})+53,127$ & 0,999 & 42,67 \\
375 & $y=-6,633 \ln (\mathrm{x})+50,696$ & 0,996 & 39,75 \\
525 & $y=-6,272 \ln (\mathrm{x})+44,928$ & 0,998 & 34,58 \\
675 & $y=-7,693 \ln (\mathrm{x})+48,05$ & 0,998 & 35,35 \\
825 & $y=-6,588 \ln (\mathrm{x})+39,16$ & 0,994 & 28,29 \\
\hline
\end{tabular}

From Table 3 the minimum thickness results used to design the radiation shield are $47.69 \mathrm{~cm}$ at the nearest distance of $225 \mathrm{~cm}$ with a constraint dose of $10 \mathrm{mSv}$ on average per year. This means that with a thickness of $47.69 \mathrm{~cm}$ at a distance of more than $225 \mathrm{~cm}$ from SAMOP can be ensured safe.

In addition to the distance and the addition of radiation shields, the time limits of radiation workers are carried out. It is assumed that the constraint dose for radiation facilities of $10 \mathrm{mSv}$ per year on average refers to the ICRP 60 provisions [12]. To find out the estimated time for radiation workers is calculated based on equation (2). The calculation results are shown in Table 4.

Table 4. Estimated radiation worker time in a week

\begin{tabular}{|c|c|c|c|c|c|c|c|c|}
\hline \multirow{3}{*}{$\begin{array}{l}\text { Distance } \\
\text { (cm) }\end{array}$} & \multirow{3}{*}{$\begin{array}{l}\text { without } \\
\text { radiation } \\
\text { shielding }\end{array}$} & \multicolumn{6}{|c|}{ Time (hours/week) } & \multirow[t]{2}{*}{6.} \\
\hline & & & & adiatic & shield & icknes & & \\
\hline & & $\begin{array}{l}15 \\
\mathrm{~cm}\end{array}$ & $\begin{array}{l}20 \\
\mathrm{~cm}\end{array}$ & $\begin{array}{l}25 \\
\mathrm{~cm}\end{array}$ & $\begin{array}{l}30 \\
\mathrm{~cm}\end{array}$ & $\begin{array}{l}35 \\
\mathrm{~cm}\end{array}$ & $\begin{array}{l}40 \\
\mathrm{~cm}\end{array}$ & $\begin{array}{l}47,6 \\
9 \mathrm{~cm}\end{array}$ \\
\hline 225 & 0,02 & 0,32 & 0,73 & 1,53 & 3,04 & 5,64 & $\begin{array}{c}12,2 \\
2\end{array}$ & $\begin{array}{c}36,9 \\
4\end{array}$ \\
\hline 275 & 0,02 & 0,46 & 1,06 & 2,27 & 5,06 & $\begin{array}{c}10,3 \\
9\end{array}$ & $\begin{array}{c}25,0 \\
7\end{array}$ & $\begin{array}{c}82,5 \\
4\end{array}$ \\
\hline 375 & 0,04 & 0,88 & 1,86 & 3,82 & 8,91 & $\begin{array}{c}20,5 \\
3\end{array}$ & $\begin{array}{c}33,9 \\
6\end{array}$ & $\begin{array}{c}119 \\
68\end{array}$ \\
\hline 525 & 0,08 & 1,64 & 3,77 & 7,55 & $\begin{array}{c}16,7 \\
8\end{array}$ & $\begin{array}{c}44,0 \\
5\end{array}$ & $\begin{array}{c}83,9 \\
8\end{array}$ & $\begin{array}{c}295 \\
02\end{array}$ \\
\hline 675 & 0,13 & 2,49 & 5,10 & $\begin{array}{c}10,5 \\
4\end{array}$ & $\begin{array}{c}18,2 \\
0\end{array}$ & $\begin{array}{c}33,4 \\
5\end{array}$ & $\begin{array}{c}67,8 \\
2\end{array}$ & $\begin{array}{c}184 \\
88\end{array}$ \\
\hline 825 & 0,21 & 4,87 & $\begin{array}{c}10,7 \\
9\end{array}$ & $\begin{array}{c}21,8 \\
1\end{array}$ & $\begin{array}{c}54,6 \\
2\end{array}$ & $\begin{array}{c}85,3 \\
0\end{array}$ & $\begin{array}{c}231, \\
20\end{array}$ & $\begin{array}{c}691 \\
47\end{array}$ \\
\hline
\end{tabular}

\section{CONCLUSION}

The minimum radiation shield thickness at the closest distance of $225 \mathrm{~cm}$ from SAMOP so that the dose value does not exceed the NBD is $47.69 \mathrm{~cm}$. The estimated maximum radiation worker time is 36.98 hours/week.

\section{REFERENCES}

1. Syarip., S., Tegas, T.B., Edi, and S., Endang, "Design and Development of
Subcritical Reactor by Using Aqueous Fuel for Mo-99 Production," Proceedings of the Pakistan Academy of Sciences: A Physical and Computation Sciences, vol. 55, no. 1, pp: 21-26, 2018

2. M., Herlan, "Pengelolaan Limbah Radioaktif Hasil Samping Produksi Radioisotop Molibdenum-99" in Prosiding Seminar Teknologi Pengelolaan Limbah V, ISSN 1410-6086, 2007

3. E., Syarip, Togatorap., and Yassar, "Molybdenum-99 production calculate analysis of SAMOP reactor based on thorium nitrate fuel," Journal of Physics: Conf. Series 987, 2018

4. T., Trikasjono, S., Elisabeth, and B., Hendarto, "Studi Penerimaan Dosis Eksterna pada Pekerja Radiasi di Kawasan BATAN Yogyakarta" in Seminar Nasional IV SDM Teknologi Nuklir Yogyakarta, ISSN 1978-0176, 2018

5. Y., Anggraini, Riyatun, Suharyana, and K., Azizul, "Evaluasi Keselamatan Reaktor Ditinjau dari Shutdown Margin pada Sistem Subcritical Assembly for ${ }^{99} \mathrm{Mo}$ Production (SAMOP)," in Prosiding Seminar Keselamatan Nuklir ISSN: 14123258, 2017

. T., Rasito, Bunawas., Taufik., Sunardi., and S., Hari, "Desain perisai radiasi untuk siklrotron DECY-13 menggunakan metode Monte Carlo," in Prosiding Pertemuan dan Presentasi Ilmiah-Penelitian Dasar Ilmu Pengetahuan dan Teknologi Nuklir ISSN 0216-3128, 2016

I., Akkurt, H., Akyildirim, B., Mavi, S., Kilincarslan, and C., Basyigit "Gamma-ray shielding properties of concrete including barite at different energies," in Progress in Nuclear Energy, 57(7), 620-623, 2010

8. I., Yuwono, "Analisis sumber radiasi interna dan radiotoksisitas atas dasar distribusi aerosol di IRM," in Prosiding Presentasi Ilmiah Daur Bahan Bakar Nuklir V P2TBOU \& P2BGN-BATAN ISSN 1210-1989

9. F., Suyatno, "Aplikasi radiasi sinar-X di bidang kedokteran untuk Menunjang Kesehatan Masyarakat," in Seminar Nasional IV SDM Teknologi Nuklir Yogyakarta, pp. 25-26, 2008 
10. A. J. A., Arma, Zat Radioaktif dan Penggunaan Radioisotop bagi Kesehatan: Universitas Sumatra Utara, 2004

11. A.S., Ouda, "Development of highperformance heavy density concrete using different aggregates for gamma-ray shielding," Progress in Nuclear Energy, vol. 79, 48-55, 2015

12. B., Prayitno, and Suliyanto, "Prediksi dosis pembatas untuk pekerja radiasi di instalasi elemen bahan bakar eksperimental," ISSN 1979-2409, 2001 